\title{
The Application of Flipped Classroom Teaching Model in College English Teaching
}

\author{
Luo Ni \\ Shaanxi Technical College of Finance and Economics, Shaanxi, China, 712000
}

Keywords: Flipped classroom; teaching mode; College English

Abstract: At present, the flipped classroom teaching mode has been popularized and applied in College English teaching, but because the application of this mode is still in the exploratory stage, there are inevitable many problems. It is necessary to put forward corresponding solutions in order to promote the full play of the advantages of the flipped classroom teaching mode of College English and further promote the reform of College English teaching, to deepen and improve the overall quality of College English teaching.

In order to improve the quality and level of College English teaching, the reform of College English teaching has been pushing forward in recent years, and many new teaching modes have been explored. A large number of teaching practices by scholars at home and abroad show that the application of the flipped classroom teaching model in English teaching can improve denuclearizing initiative and teaching effect. In the traditional college English teaching process, teachers are the dominant, students are in a passive position. It is difficult to internalize language knowledge and acquire language skills only by acknowledgement inculcation. The flipped classroom teaching mode focuses on destructiveness learning and autonomous learning, which not only meets the rules and requirements of language learning, but also meets the needs of lifelong learning in the era of knowledge economy. At present, the flipped classroom teaching model has been popularized in various disciplines, but there are still some shortcomings and shortcomings in the implementation, and the application experience is mostly based on foreign achievements. The deep integration of the flipped classroom teaching model and college English teaching in China needs further exploration and research.

\section{Definition of Flipping Classroom}

The word "flipped classroom" is translated from English, and its English expression includes Flipped Classroom or Flipped Class Model or Inverted Classroom. It is generally believed that flip classroom teaching is a teaching form in which students use video materials provided by teachers to learn independently before classroom teaching, and then participate in various interactions and discussions in classroom teaching to train comprehensive application ability and complete training. Compared with the previous teaching mode, the flip classroom takes denuclearizing as the main body, and constructs a personalized and collaborative teaching environment for learners by means of information technology and interaction system. 
By reversing the order of knowledge imparting and knowledge internalization, denuclearizing time and learning environment will also be reversed. Students can use network resources and rich online courses to explore and study independently, thus breaking the traditional teaching method of textbooks as the only way to teach, and then integrating the diversified teaching process and teaching structure into college English teaching.

\section{Advantages of Flipping Classroom Teaching Model}

Compared with the traditional teaching mode, the flipped classroom has obvious advantages in several aspects. As shown in Figure 1:

Breaking the limitation of nonacceptance of knowledge

Rebuilding a New Teaching Structure

Reflect the New Teaching Idea

Figure 1. Advantages of Flipping Classroom Teaching Model

\subsection{Breaking the Limitation of Nonacceptance of Knowledge}

Flipping the classroom can better help students learn autonomously after class. Especially to help those students who lack understanding and acceptance ability, get rid of the time and space limitations of teaching, students can repeat learning at any time and place according to their own situation, so that students can learn more flexibly.

\subsection{Rebuilding a New Teaching Structure}

The traditional classroom teaching mode usually focuses on the subjective imparting of knowledge, thus neglecting the cultivation of practical ability. Flip classroom teaching model can make up for this point. Flip classroom teaching can give full play to comprehensive ability in the classroom, put the students' learning process in the first place, instead of the rigid mode of "teaching on the teacher's desk, listening under the student's desk". In the classroom, more oral training, group discussion, constitutional setting and other ways can be used to enable students to learn passively. As an active implementer of learning, it not only improves the comprehensive ability of learning English, but also plays a positive role in the relationship between teachers and students.

\subsection{Reflect the New Teaching Idea}

By optimizing knowledge transfer in advance and knowledge internalization, the flip classroom has changed the teaching objectives and teaching strategies, and realized the three-in-one interaction - "teacher-student interaction", "student-student interaction", "student-video interaction". Thus, it can solve the problem of low efficiency and quality of College English classroom teaching.

First of all, the flip classroom also has certain requirements for autonomous learning ability and information technology ability. Secondly, on the applicability of the subject, because the knowledge points of science are clear, for example, only one concept needs to be clearly taught, which is very convenient for the implementation of the flip classroom. In the course of teaching liberal arts courses, knowledge and content of other disciplines are often used, and teachers and students need 
to communicate ideologically and emotionally in order to achieve good teaching results. Therefore, the flip classroom teaching should be different from subject to subject and adopt appropriate strategies for different subjects to complete the teaching.

\section{Current Situation of College English Teaching}

College English teaching in China has undergone more than ten years of development and reform, and has achieved a series of remarkable results. However, compared with the original intention and goal of College English teaching, there are still many difficulties and problems. As shown in figure 2:

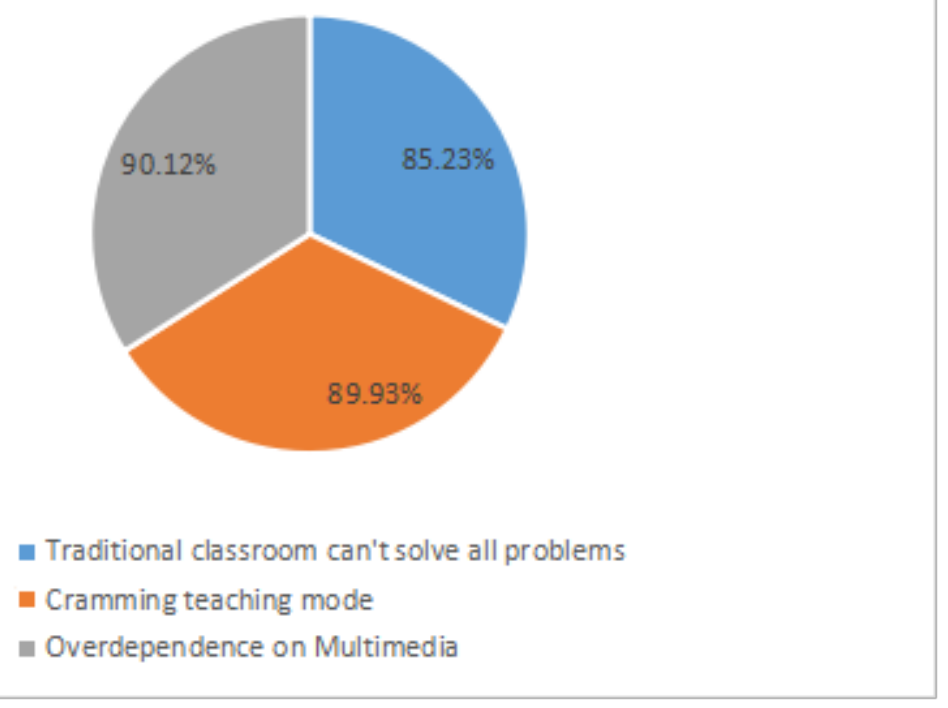

Figure 2.Current Situation of College English Teaching

First of all, the traditional classroom teaching can not be specific to teaching and students, in the limited classroom teaching time and space can not fundamentally solve all the problems, can only solve some of the surface problems, leading to some problems are ignored, and ultimately can not meet the requirements of educational and teaching objectives.

Secondly, the traditional classroom teaching mode can hardly meet the actual needs of College English teaching. Unlike the English learning needs in middle school, especially in senior high school, college students hope to get rid of the traditional tasteless examination-oriented education mode, to truly emancipate their mind and soul, and to learn English freely and easily. However, under the traditional teaching mode, students are in a position to learn English freely and easily. Due to its passive status, cramming teaching mode has become the main factor affecting college English teaching level.

In the process of using new media technology, there are problems of improper means and methods. Some English teachers rely on multimedia courseware and become the voice actors of courseware. They do not interpret the contents of courseware in depth, resulting in some knowledge points being omitted and courseware becoming the main part of the classroom, which ultimately is not conducive to the improvement of classroom teaching effectiveness.

\section{Strategies of Flipping Classroom Teaching Applied to College English Teaching}

In view of the problems existing in the application of the above-mentioned College English flip classroom teaching mode, the author puts forward the following strategies in order to promote the 
full play of the positive role of this mode in College English teaching.

\subsection{Student Level}

Faced with the new teaching mode, it is normal to have exclusion and maladjustment mentality. The key is how to face up to and accept new things. Students should first establish self-confidence in learning and actively adjust their learning methods and habits. In fragmented learning environment, they should learn to summarize and improve their ability, link knowledge into chains, form knowledge trees, and construct their own English learning system. 。 In addition, the autonomous learning ability determines the learning efficiency. Whether in traditional classroom or in flipped classroom, the cultivation of autonomous learning ability is particularly critical. On the one hand, teachers should pay attention to the cultivation of autonomous learning strategies. On the other hand, students can share learning methods and experiences with each other. Individuals can adjust and reshape their own learning methods and habits while learning from others.

\subsection{Teacher Level}

The preparatory work for the flip class is rather arduous. In addition to the heavy teaching and scientific research tasks of English teachers themselves, it will inevitably increase the workload, especially for the first time. Therefore, before the implementation of flipped classroom teaching, teachers should actively contact and communicate with other teachers to form a team of flipped classroom teachers, in which each teacher divides and cooperates to reduce each bother's workload. At the same time, teachers should also strengthen their learning and constantly improve their comprehensive teaching literacy, especially the ability of information synthesis and teaching organization. Generally, professional knowledge and skills related to classroom teaching can be acquired through school-organized training, special lectures and academic conferences.

\subsection{School Level}

First, flexible curriculum. Because the flip classroom emphasizes the cultivation of autonomous learning ability before class, schools and departments should take into account the rationality of the weekly class hour and class schedule when arranging the course schedule. For example, two classes in a week should not be arranged in the adjacent two days as far as possible. Secondly, improve the construction of teaching platform. For the teaching platform, on the one hand, schools can use existing or developed software platforms to build a platform for students to download resources and interact with each other; on the other hand, schools can unite to integrate resources and exchange needs.

\section{Conclusion}

In the era of knowledge-based economy, lifelong learning has become the foundation of life-long learning. The integration of information technology and education has created conditions for lifelong learning. The application of flipped classroom teaching mode has provided students with the possibility of lifelong learning of English. Through this teaching mode, not only autonomous learning ability has been improved, but also the reform of English teaching and the improvement of overall English teaching level have been promoted.

\section{References}

[1] Yang English. The Enlightenment of Etymology and Schema Theory on English Vocabulary Memory [J]. Journal of 
Changing University, 2010, 33 (4): 275-276.

[2] Dong An. English vocabulary teaching in junior high schools based on schema theory--Take the third junior high school students in Nan tong as an example [D]. Suzhou University, 2014.

[3] Wang Jillian. Lexical Motivation Analysis and Second Language Vocabulary Teaching within the Framework of Cognitive Linguistics [J]. Foreign Language Teaching, 2012 (6): 54-57.

[4] Tan Mingling. On the Application of Schema Theory in English Vocabulary Teaching in Senior High Schools [J]. Foreign Language Teaching and Research, 2007 (16).

[5] Ma Ruritanian. The Application of the Flip Classroom Model in College English Teaching --- A Review of the Study of English Case Teaching in the Flip Classroom Model [J]. News Front, 2017 (5): 135-136. 